\title{
Political economy of the humanitarian actions
}

\author{
Jacques Fontanel, Albane Geslin \\ War, Peace and Security (Ed. Jacques Fontanel and Manas Chatterji), \\ Emerald, Bringley, 2008
}

\begin{abstract}
Summary
There are some opposition on the interpretation of international military intervention between democratic countries and UNO. With the process of the globalization and the development of the transnational networks, the wealth and the power are not any more determined by the only territorial authorities, in order, for instance, to insure the protection of the ecosystems. Human rights, protection of minorities and rule of the law are supposed to be common values of the contemporary world order. The promotion and the protection of human rights lead to the international absolute condemnation of the genocides, the crimes against humanity and the ethnic purification. With the creation of international penal courts, the political leaders became responsible individually of the crimes of their regimes. The humanitarian intervention is sometime an action of force, organized at the international level by States to fight against organized and systematic violations of the humanitarian right on the territory of another State. There are two " political economies of the humanitarian ", expressed in the civil domain or in a military intervention.
\end{abstract}

The political economy of the humanitarian is a new or a very old concept. If we have the main reference of the humanitarian interventions of military type such as they were applied during this last decade, there is no analysis of political economy on the question. On the other hand, if we introduce in the concept of humanitarian actions the economic decisions which take into account the specific actions which are mainly interested by the satisfaction of the basic needs of the people, then the concept is already more ancient, but not older of two centuries. Since the end of the cold war and the collapse of USSR, the traditional threats have been modified.

Today, the international security makes less reference to the military dimension. In its widest sense, the international security is insured when on one hand the peoples feel safe and on the other hand their fundamental needs are satisfied. Nations are secure when they can guarantee the rights of their citizens and when they can protect, on the long run, the environment for the future generations. Today, a lot of studies speak about ecological disaster, about demographic "bombs", drugs, corruption, but especially about ethnic purge (real strategy conducing to the massacre or the exile of the civil populations). About 40 million refugees were moved, without that the vital interests of major powers are concerned. Seize by the horror of the holocaust, renewed in Cambodia, the democratic States tried to clear their responsibility in front of the history, by conceiving, under the prickle of non-governmental organizations and media, by modifying or by applying the rules of a new international law. 
So, if the former President of the United States Bill Clinton wished to develop the humanitarian intervention to protect universal values, even with the intervention in the internal affairs of sovereign States. The ideology of the humanitarian benefited from new supports. With the terrorism attacks, the will of the "duty to interfere" is growing and conduces to the Afghanistan and Iraq wars. There are some opposition on the interpretation of international military intervention between democratic countries and UNO. In the new system of current security, there are three fundamental changes, managed partially by the system of United Nations:

- With the process of the globalization and the development of the transnational networks, the wealth and the power are not any more determined by the only territorial authorities, in order, for instance, to insure the protection of the ecosystems.

- Human rights, protection of minorities and rule of the law are supposed to be common values of the contemporary world order. The promotion and the protection of human rights lead to the international absolute condemnation of the genocides, the crimes against humanity and the ethnic purification. It is the progressive consecration of the doctrine Kouchner-Bettati on the humanitarian intervention, the right or duty of assistance for people or minority in danger. It comes along with the development of the process of democratization.

- With the creation of international penal courts, the political leaders became responsible individually of the crimes of their regimes.

In this context, the political economy of the humanitarian supposes two dimensions. First, it makes reference to the "voluntary" role of the political system for the satisfaction of the needs of the biggest number. It supposes a collective action, engaged by the State or by the non-governmental organizations, to reduce the poverty, improve the conditions of life of each and insure the dignity (refusal of the slavery) and the security (fight against the threats and the violence) of all people. Jan Tinbergen considered that $70 \%$ of the decisions in the world were the fact of individuals or households, $15 \%$ by the local governments and $12 \%$ by the governments. It would be necessary to leave at least $3 \%$ for decisions of common world interest ${ }^{1}$. It is thus a question of international public goods creating spaces of solidarities between the States and all the countries.

Second, the humanitarian intervention is sometime an action of force, organized at the international level by States, individually or in group, to fight against organized and systematic violations of the humanitarian right on the territory of another State. It is about a new concept of law, what does not mean that it did not already serve in past, notably in religious wars. The appeal to the violence is forbidden. Since 1945, States lost the war right, even if in the international practice nothing such happened. The equality and the integrity of the sovereign power of States stay the main foundations of the international law.

The "duty to intefere" intervention must not be mixed up with the humanitarian intervention, which is peaceful, restful on the assistance to the victims of armed conflicts or natural disasters. It is based on specific, vast and grave infringements on the humanitarian right, it is steered against an opponent, it implies the usage of the

\footnotetext{
${ }^{1}$ Tinbergen, J. (1993), Paix économie, in « Economistes de la paix », .Fontanel, (Ed.) ; L'économie en plus, Presses Universitaires de Grenoble, Grenoble.
} 
force and the other coercive means in order to stop the massive and violent neglects in the humanitarian right ${ }^{2}$. It is interesting to note that this " humanitarian right " concerns the Marxian concept of "formal rights", i.e. the liberties, the human rights and the exercise of the democracy. In other words, they concern almost never the questions of health or food, and this reduction of the area cannot satisfy all the economists. It is thus necessary to redefine the international solidarity. There is two " political economies of the humanitarian ", expressed in the civil domain or in a military intervention.

\section{The political economy of civil humanitarian actions}

The political economy of humanitarian civil is not really a disciplinary field of the economics. It limits generally its investigations to the aid to the developing countries, what constitutes only a part of its contents. Two main questions on the civil humanitarian economic policy must be analyzed.

- At first, the role of the humanitarian is often the object of debates inserted into very general theories.

- Second, the "humanist" perception of the economy knows important difficulties of recognition.

\section{I.1. What is the economic signification of civilian humanitarian actions?}

The political economy did not practically exist as such before half of the second millennium. The analysis of humanitarian civil was often neglected by economists more worried to put in evidence the economic mechanisms that to analyze the basic needs. So, several theories give a sense and a social efficiency to the humanitarian actions. Contrary to the other sciences, it is necessary to say that the economic theory accumulates analyses without an obsolescence process.

\section{A) A political economy far from the basic needs satisfaction}

The humanitarian conception of the economy can be developed only if the fundamental objective recognized by the economic action is the welfare of the population. Now, several analyses refused to take into account this hypothesis.

- For the Mercantilism School, the fundamental objective of the economy is the power of the Prince (or of the State). In these conditions, the "humanitarian" character of the economy is not an objective in itself. So, Colbert refused to export the French agricultural productions in surplus in Spain in famine to weaken the Spanish monarchy. On the other hand, he wished to have people fed well and well looked in order to insure the prosperity and the safety of France. In this context, human rights are those that indeed improve the power of the Prince.

- For List and the German historic school, the state economies have to protect themselves against the products of foreign countries and look for the realization of

\footnotetext{
${ }^{2}$ Sur, S. (1999), Aspects juridiques de l'intervention des pays membres de l'Otan au Kosovo ; Défense nationale ; Décembre, p.50.
} 
their natural boundaries, eventually at the price of the war. In these conditions, they cannot have a humanitarian policy towards foreign countries, except when military and strategic conditions could justify them. In other words, even if the needs of people will be doubtless satisfied by the generalization of the market economy, this one will be engaged only when the States satisfy the necessary national conditions, that is the realization of the natural boundaries. In that case, the humanitarian intervention can exercise only against the "wild" parts of the earth, to which it is necessary to bring the Christian civilization and its rights and obligations. This "humanitarian" conception is not so opposite to the modern situation.

- All the theories on the notions of war or economic weapons are obviously taken away from a "humanist" conception of the economy. For example, the strategy of the impoverishment by the military effort tries at first to make more and more difficult the satisfaction of the needs of the inhabitants of enemy countries. It has the ambition to impoverish the enemy and to provoke appropriate social contests for the revolutionary situations or for the collapse of the economic system. In these conditions, it is difficult to speak about humanitarian policy. Also, the former USSR collapsed, for lack of not having known how to manage the very fine "knife edge" which would have allowed it to reconcile, in a competitive world and at the same moment, the economic development and the international security of socialism, without that the first one is condemned by the excessive accent granted to the satisfaction of second.

\section{B) Ineffective and dangerous humanitarian political}

According to the liberal theorists, the opening of the economic borders promotes at the same time the economic and social progress and it favours the peace. Every country has to specialize in the products in which its advantage-cost is the best. In these conditions, the humanitarian policies are not desirable if they reduce the economic development potential in longer run. Several economic analyses go to this sense.

- If Adam Smith condemns at the same moment the slavery and the colonialism, it is mainly on the basis of an economic thought (not based, at least, on a humanist morality). So, he called of his wishes the strictest application of the individual interest, fundamental factor of realization of the " invisible hand ". The "humanitarian" interventionism did not seem interesting for economic development issues.

- Malthus established a law of population, always opposed to the public assistance of poor people, by the famous parabola of the cake to be shared. The "humanitarian" actions weaken the whole system. That is why he considers that the application of the economic law of the market must be respected. Unless applying a voluntary control of the births by the abstinence, there will be either threat of wars, or famine.

- For Marx, the humanitarian policy has no sense in the capitalism. The defence of the formal liberties is only a means of bourgeoisie domination, which organizes States with the aim of the defence of its own interests. This conception is not developed any more as well as it was at the time of the cold war, even if it is still supported by numerous progressive States which see in the humanitarian intervention the expression of the western domination on their cultures and their customs. 
- For the neo-classic school, the system of market economy has to lead at the same moment to the equilibrium and to the optimum. It is not thus healthy to suspect a humanist policy other one than the one who consists in defending the basic ideas of the capitalism on the freedom of the business and the industry and the superiority of the individualism.

- On the other hand, numerous utopian socialists developed the idea according to which it would be necessary "to civilize" the not European peoples, and to apply to them, by force is useful, the fundamental rules of the western humanism. In that case, the "humanitarian" politics action is based on the imperialism of the thought and the idea according to which " the white man " defines the rules of the kingdom of God or of the Humanity on earth.

- Today, most of the developed States consider themselves insufficiently developed to bring a global humanitarian aid to developing countries. On the other hand, important efforts are made to allow them to apply the rules that prevail in the western democracies.

These ideas are still widely dominant in the contemporary economic analysis. Naturally, some helps are brought in the absolute conditions of distress, but it is often in the cases where, on the initiative of the media, the richest countries rediscover the bad consciousness.

\section{C) A political economy at the service of all people}

Following the Keynesian thought, François Perroux defined the foundations of the economy on the basis of a triple requirement that he called the costs of the human, namely to feed people, to nurse the individuals and to release the slaves.

- The function of fight against the famine is natural in the economy, and nevertheless our century always lives with the misery and the sub-nutrition.

- To nurse people also answers this will of respect for the life, but the hope life diverges strongly according to Nations and their level of development.

- Finally, the requirement of the liberation of the slaves, according to the François Perroux's emphatic term, makes doubtless reference in the necessity of the growth, but not in any situation. The human need a true life, an existence which is not only turned around the imperative and constant requirement of the work in a universe remote from rules of the freedom and from the democracy.

These ideas are resumed by Amartya Sen, who analyzes the advanced economy as a society able of supplying important rights for each, what he calls "entitlements". In other words, a nation will be developed only when it will be capable of insuring the freedom, the democracy, the equity (and not the equality), and the respect for all and for each.

These conceptions of the development which it is ceaselessly necessary to remind not to forget that the economic development is made by the man and for the man in an economic universe in which the dominant thought often advocates that « the man is always a wolf for the man »- underline the necessity of assuring each person, today and tomorrow, his " costs of human » or his "entitlements", but they do not insist enough on the idea of the duration of the economic development and on the fact that every generation is also responsible for the following one. In other words, the planet belongs to those who live in it and to those who will live in it. Now, so that the development is "sustainable", it is necessary to respect the rules of the nature, but also 
to fight against the destructive tendencies of the human nature. If tomorrow the earth is only a deposit of garbage, it will not be any more question of development, but rather the reduction of the satisfaction of the needs of the persons.

The United Nations Organization promoted, from its origin, the disarmament. "There is a narrow link between the disarmament and the development. The progress of the first one would contribute largely to the realization of the second. The resources freed released as a result of the application of measures of disarmament would thus be dedicated to the economic and social development of all the nations and to serve for filling the economic gap which separates countries developed by developing countries ". This analysis makes the hypothesis of the peace and the uselessness of the armament. However, the international security is not a free service. It is about a conquest, in the same way as any satisfaction of the economic and social needs. The security constitutes a decisive factor of the " sustainable development ".

The large countries do not generally use weapons in their economic competition, but this one is also translated sometimes by deaths of people, when it is impossible, for ideological reasons, to improve the situation of the poorest. The underdevelopment probably killed ten times more that all the war actions since 1945. It is a dangerous error to believe that we stop the useless death of people by destroying weapons. The economic disparities based on the domination create the conditions of the misery. Furthermore, most of the models of arms race contain a parameter of fatigability that indicates the degree of economic and social acceptance of the effort of armament. So, in an inevitable way, the military sector and the economic development are put in opposition.

\section{I.2. The humanitarian policy, as a new perception of the relashionships between human beings}

With their effective and intelligent action, non-governmental organizations inform public opinions, which did not miss to call to the political powers. Even with the domination of the ideas of globalization and liberalism domination, their excesses begin to be listened. It is so on one hand that the globalization raises the problem of the American domination and on the other hand that the liberalism does not offer its advantages to an increasing part of the suffering world population. The modern humanitarian policy exercises in very different conditions of power between States and debatable consideration of time.

\section{A) The low humanitarian relations between States}

The underdevelopment constitutes a threat for the world peace. For the partisans of the New International Economic Order, the disarmament appears rather as a consequence of the development. In these conditions, the processes of disarmament intervene at first by the development of the poorest countries and even in certain cases, by a fairer redistribution of the world resources. Now, these ideas developed in the 70s, were gradually abandoned by the development of the economic liberalism and the globalization process. The power based on the force is supplanted by the development of the intelligence applied to economy and strategy. The interests of

States are not reduced inside boundaries; they define themselves in terms of 
economic health and cultural identity. States use all the ranges of the strategies. Now, the appeal to the physical or economic violence still has not for objective to dominate a well-defined political entity. It is a question of defending permanent or incidental public interests. In this context, the Atlantic Alliance saw its role developing to fight against the instability in Europe provoked by the " grave economic, social and political difficulties, including ethnic rivalries and territorial disputes which know numerous countries of central and oriental Europe " (council of Rome in 1991). It is thus about a wide conception of the security which interests all Europe, emphasizing the diplomatic means and allowing the use of soldiers outside the zone.

The humanitarian action is included in a moment where the powerful countries try to obtain from the poorest countries a general agreement applied on the western values and economic system. The western world shows an important solidarity, very powerful with the NATO, a device of economic security (European Union) and democracy (OSCE). These institutions structure this first world. Countries obtain a mutual profit, that of the stability who allows giving a solid pedestal to the economic merciless competition. This organization aims at the elimination of the traditional war in this world. But there are victims:

- The European construction stays under the American leadership, but the effects of irreversibility are not reached yet.

- This system leaves at a secondary role the countries formerly under Soviet custody. A lack of generosity and an excess of strategic realism forbid another massive democratic and economic aid to peoples who give in to the mafias.

- The absence of generosity in the East has its correspondence in the South, safe for the countries which have public interests with the western system, either strategic (Israel), or on finance area (Arabic peninsula). Africa should be a continent abandoned in its fate, but the oil and commodity extractions.

- The proliferation of weak and unstable States in the suburb of the euro-Atlantic system provokes reflexes of distrust and tends to multiply barriers between the worlds.

In the second world, the one who leaves the Third World, we obtain a proliferation of States and a disappearance of the other political entities. This world of weak States that fall to pieces and fragment is under the power of human beings, sometimes deprived, often criminal or illicit interests, controlled by the force. Because of the bad functioning of States, Mafias often govern these, where some monopolizes natural resources and international aid, which criminalized their detention and their use. The State is not more than the folding screen of sectional interests. The ideologies, the religions or the sects reserve the wealth or the monopoly of the violence to the "elected members", with often an ethnic base. In the XXIth century, the mafias risk to take it. There are constantly new damages to the human dignity and the universal consciousness.

Today, these two worlds live. The first world has a moral and authoritarian vision of the world organization. It established a battery of principles, constraints and obligations, which answer the western culture, in the defence of acquired advantages. In the second world, there are the rebel States, which threaten the peace and the international order. The big powers try to eliminate the war by the technology, but they have to face the barbaric and sophisticated terrorism. The violence is now intra and infra state. The armed struggle joins in a more complex and regionalized political 
context. There are so small dynamics (crumbling and toughening of the fight), identity (search for cultural specificity), community (assertion of the unity of the group), nationalists (spirit of collective conquest), separatists or freedom fighters, to which the media give an excessive resonance chamber. The violence of these fights is unlimited. The purposes of the war intervene on the borders, the demands of territories, the will of a bigger autonomy or the fight for the power. The civil populations serve as objectives. The regular armies are assisted by militias, bands, militarized criminal conspiracies (Yugoslavia, Sierra Leone, Liberia, Somalia).

We are still in the world of States, of the society of States, which try to banish the military war and the use of the military violence in their own balance of power. There is a world of companies and particular interests, with not state character and with varied objectives (survival, defence of the ideas, safety, harnessing of wealth). This world is capable of breaking all the existing laws, without recognition of the borders and States.

\section{B) The temporal conception of Humanitarian policy}

An economic development will be said "sustainable" when he allows an improvement of the conditions of life of each human being (according to moreover different rhythms), without questioning the potential development of the future generations. This concept differs from the notion of growth, notably that of the Gross domestic product, which expresses at the same moment a conception profoundly onedimension of the economy and a short-term vision of this one. So a country can have a strong economic growth, but profits of which are reserved for the smallest number or the realization of which supposes forms of slaveries.

The development is considered as a situation of progressive and irreversible improvement of the state economy, in aid of the human beings who compose this one. To speak about "sustainable" development is, in this context, a pleonasm. A development, which would not "be sustainable", would thus be directed only to economic values of short run. However, behind the "sustainable" term settled down interesting values that the economy, in its large egoism, seems to have forgotten. It is there so of the ecology, the environment, the health, the education, the safety, but also in a more general way the blooming of people.

In spite of satisfactory short-term results, if the ecology is not respected, in longer run, the economic crisis will be inevitable and it will result from it a strong recession and a decrease of the resources put at the disposal of the future generations.

\section{The political economy of humanitarian military}

There are five modifications of the international system since 1989:

- The erosion of the nuclear threat and the loss of legitimacy of atomic weapons in the international reports are fundamental characteristics.

- The threats changed, less turned on the territorial ambitions, the conflicts of sovereign power or the national independence. They concern terrorism, drug, secret immigration or the "dirty" money. 
- The conflicts are fewer and fewer to inter states and more and more intra states, so exposing to the violence the civil populations: Bosnia, Kosovo, Somalia, Rwanda, Liberia, Sierra Leone, etc.;

- The western strategy is turned to the obsession of the " dead zero ". Probably, with the Iraq war this situation is softening.

- Since 1990, the Security Council increased its presence in the field of the preservation of the peace, notably in the application of the economic sanctions or by the commitment of pursuit against the authors in infringements on the humanitarian right.

Any peace situation is not inevitably preferable at a situation of conflict, notably when it is based on the tyranny, the slavery or the exploitation and the disregard of the right of the man. In these conditions, the conflicts intra and inter state question the international community, widely informed by the media. It is then impossible for the governments to be neutral. However, the expression of the government policy can conduce to a simple declaration to a military operation, often within the framework of rules fixed by the international community. The "humanitarian" justification is easy to apply by the western major powers, except for the payment of the debts incurred in this occasion.

\section{II.1. The disappointing effects of the "humanitarian" action}

Because of little respected principles, the results of the humanitarian action are disappointing, even when the engaged costs are not unimportant, and turn out even catastrophic for certain regions of the world.

\section{A) Les principles}

It is often difficult to distinguish the operations engaged in conformity with the humanitarian intervention of those who are based on the preservation of the peace (peacekeeping operations). Sometimes, the second proposal has for vocation to succeed to the first ones. These military operations have a lower, moderate cost $(0,5 \%$ of the world military expenditures), what can make them economically justified. Their objectives are:

- To dissuade an aggressive behaviour,

- To force belligerent parties to adopt a behaviour corresponding to the international rules (war criminals, embargoes, legality of the government)

- To bring a humanitarian assistance,

- To support a peace process, by a pacification of the spirits, on the basis of human rights and by the implementation of democratic institutions.

Besides, the new armed forces are more and more effective to solve the specific problems of the humanitarian intervention. However, the difficulties of application of the military intervention in humanitarian purposes are not easily solved.

\section{B) Les results}

The UNO and the regional institutions supported successfully the establishment of the peace in several conflicts (African Central Republic, Guatemala, for instance), but 
this action was more debatable in Bosnia and Herzegovina, in Georgia, in Sierra Leone or in Tajikistan. It was a failure in Angola.

Unmistakably, the air forces of the Alliance filled their mission and obliged the Serbian army to withdraw from Kosovo. However, the political consequences of the war were catastrophic for people of the Balkans and the relations with Russia and China were deteriorated. The Serbian staffs use the civil populations as shields, in expiatory victims. The civil war had killed 2500 persons. 10000 died under bombardments and several hundreds of thousand persons were moved, the stability of the countries of the region was strongly shaken. Kosovo was in ruin, in Serbia the economic infrastructure was largely annulled. NATO intervened in a civil war, refusing the independence of Kosovo. Besides, the western intervention in Kosovo asked the question of the distinction between partners and opponents, on a battlefield covered with women and with frightened and starving children. Now, the Westerners have to distinguish the humanitarian targets and the human civil targets, what supposes the use of more and more lethal weapons.

It would be necessary to prefer the preventive diplomacy. The UNO often compromised itself in the operations of preservation of the peace, the utility of which is debatable. The failure of a preventive diplomacy often supposes the use of forces for the preservation of the peace at the request of belligerent parties. The appeal to the international authorities intervenes when the situation is already conflicting. The UNO has to intervene with a moderate use of the necessary force.

\section{C) The price of the military operations}

There were more than 50 operations of preservation of the peace of the UNO since 1946, for a global cost lower than 25 billion dollars spent by United Nations. The costs depend on the operations, 3,3 billion dollars in 1998 to 1 billion in 2006. Now, unlike the operations led under the custody of the UNO, the NATO operations do not give place to repayment by the Alliance. The financing must be found by internal budgetary solutions ${ }^{3}$.

The staffs of the UNO involved represented about 10000 persons in 1988 to more than 73000 in 1991 and 20000 in 2006. The budget evolved from 230 to 1600 million dollars between 1988 and 1996 (among which $31 \%$ for the United States which do not pay and ask for a reduction of $25 \%$ of the U.S. participation). There main contingents are Russian, Bangladeshi, Pakistani and Indian. Europe participates for $21 \%$ of the total personnel, among which $2 \%$ for France.

These expenditures are important. However, the directly attributable additional costs for the peacekeeping operations is not excessive for industrial nations such as the United States, Germany or France. It represents less than 0,2\% of the world military expenditures.

\section{II.2. The " perverse effects " of the humanitarian action}

\footnotetext{
3 The Commission of the finances of the National Assembly in France estimates the additional cost of the outside Operations (OPEX) at 6,6 billion francs for the participation in the war of the Bay and for the Balkans in 5,2 in 1996, 3,3 in 1997, 2,1 in 1998 and more than 4 billion francs in 1999.
} 
There are five main "perverse effects" of the humanitarian action : the various economic and political values of deaths, the complexity to apply and rationalize strategies, the difficulty of the financial assessments, the limited interventionist enthusiasm and a very selective "humanitarian" policy.

\section{A) The preferred protection of the soldiers}

The soldiers and their weapons are mainly concerned by the humanitarian action. It is a question at first of avoiding the human, military and civil lives, but also the material. Only three planes of the NATO did not return from Kosovo war. From an economic point of view, it is necessary to know that an American cruise missile costs 1 million dollars, one F117, 45 millions, one Apache 15 millions and one B2 2 billion dollars. The financial commitments are important.

The State humanitarian action is often more concerned by the protection of the life of the soldiers that of that of the civilians that it is supposed to protect. The military deaths can be listed and are badly accepted by the international community. Before 2001, the government of United States avoided the military contact. Furthermore, if they contributed at the level of $5 \%$ of the total of the troops engaged in the operations of the UNO in 1996-1997, the European Union intervened in competition of $36 \%$. For these operations, the diplomatic profit removed by Europe is derisory.

\section{B) The inherent difficulties of humanitarian strategies}

The Military Operations other than War (MOOTW) are actions that lead to the use of the military capacities in all their dimensions, without establishing for all that a war action. They are normally intended to dissuade the war, to resolve the conflicts or to promote the peace. They are driven in an environment of humanitarian assistance, but also in a hostile environment, in a situation of civil disorder and terrorist actions. It is necessary to distinguish the operations of support for the diplomacy, the peacekeeping and the peace enforcement. This last operation is more binding, because it does not imply an assent of the potential belligerent parties, it supposes the defence of a philosophy (the human rights) which leads to a kind of partiality in the steady forces or the ideas to defend, and it authorizes the appeal to the force in the application of a mandate.

Table 1 - The degrees of application of the peace operations

\begin{tabular}{|l|l|l|l|}
\hline Variables & $\begin{array}{l}\text { Support for the } \\
\text { diplomacy }\end{array}$ & Peacekeeping & $\begin{array}{l}\text { Intensification } \\
\text { of the peace } \\
\text { support }\end{array}$ \\
\hline Assent & High & High & Weak \\
\hline $\begin{array}{l}\text { fosces } \\
\text { fort }\end{array}$ & Weak & $\begin{array}{l}\text { Weak, within } \\
\text { the framework } \\
\text { of the self- } \\
\text { defence and the } \\
\text { mandates }\end{array}$ & $\begin{array}{l}\text { Being enough } \\
\text { for forcing }\end{array}$ \\
\hline Impartiality & High & High & Weak \\
\hline
\end{tabular}


The operations are offensive (fight at the enemy), defensive (actions to prevent an enemy attack), of stability (military and diplomatic deterrence) and support (to calm the sufferings of the populations). The humanitarian assistance belongs mainly to this last type of justification.

These conflicts establish the inadequacy of a strategic system, which does not take into account the various social rationalities. Its failure is lived as the outcome of a fundamental strategic confusion: the use of the soldiers at a strategic level (the purpose is not to destroy, but to force States to a diplomatic fold) and the bad use of armed forces (humanitarian, preventive diplomacy). Better interactions between the lethal and not lethal weapons are needed. Bombardments were not decisive. The gradualism chosen by the politics is mainly considered as against the decisive use of the force. The humanitarian military aid supposed new weapons and new strategies. And then it needs more outlays.

\section{C) What leader, the Atlantic Alliance or the UNO?}

The Security Council lost a part of its prestige. It was incapable to make respect the resolutions against Saddam Hussein, China prevented the minor operations of preservation of the peace in Guatemala and in Macedonia, it threatened to make it so much for Haiti. The weapon of the veto does not work well, but major powers do not want to be deprived from it.

Because of the obligation of the President of the United States to ask the Congress to declare the war, Bill Clinton preferred to apply the capacities of "War Powers Resolution", who requires only information of the President to the people representatives. It is thus about a MOOTW, the operations of which were likened for all that to a war. Besides, in this frame, the government of the United States did not respect the Charter of the United Nations (article 53, chapter VIII), which establishes that, nobody " coercive action will not be begun by virtue of regional agreements or by regional bodies without the license of the Security Council ". Now, the Americans did not wish to undergo a blocking of the Security Council, considering the possible veto of Russia and China. They tried to demythologize the mandate of the UN, by exploiting that their politics is the only possible for the international stability. In any case, the criterion of support of the United States is based at first on the American interests. The humanitarian disasters connected to violence, as well as the interruption of the democracy or the respect for human rights, constitute important, but second objectives with regard to the previous objective. The public opinion has besides to express a self-important support.

The Atlantic Alliance sometimes tries to be equipped with a crown which returns to the UNO, the only international organization of the rights universally recognized. The United States do not take even any more care of advancing masked behind the banner of United Nations. Not to be hindered in its action, the government of the United States put deliberately aside the UN Security Council.

However, according to François Mitterrand's words, the Atlantic Alliance did not have to become either the Holy Alliance. It has no vocation to take charge of while assuming powers in the not military domain for example. It is not either an alliance of interests allowing the United States to take the Europeans all around the world 
according to a collective interest, with or without the assent of the UNO, against States considered terrorist. If NATO has to intervene it has to be in keeping with the international rules, the UNO remaining the source and the guarantee of the world legal order

\section{D) Des difficulty of financing}

The finances of the UNO stabilized, with a "zero" growth of its budget over several years. But its position "in cash" is very weak, with the persevering decline of the rates for the preservation of the peace. Following the liquidation of heavy operations, the balance of the preservation of the peace (peacekeeping) decreased from 1697 million dollars in 1992 to 2700 millions in 2001 and 2260 millions at the end of 2003 . The whole budget has a deficit that is from 664 in 1992 to 1823 million dollars in 2001 and 1066 million dollars in 2003.

The taxpayers pay with a lot of delay. The United States remains the principal debtor of the operations of preservation of the peace (50\% of the total amount). The UNO owes some money for the equipment and the services in France and for the troops of Finland of Pakistan and Bangladesh. Only, however, the Americans jib paying their arrears.

The common credits of the UNO were 2.6 billion dollars for both biannual exercises of 1994-1995 and 1996-1997, and 3.2 billion dollars for 2003-2005 ${ }^{4}$.

\section{E) A limited enthusiasm interventionism}

The governments are very reluctant to send their troops. 6 months were necessary to gather 5500 soldiers for Rwanda, while 19 governments had undertaken to send 31 000 soldiers. The failure comes as well from the bad will of the belligerent parties as the members of United Nations themselves. Now, it is necessary the application of the force to make cross the humanitarian convoys, the protection of the civil populations in the zones of safety, the maintenance of law and order. It leads to a delegation of power in groups of member states. The military interventions were organized always with hesitation and often with bad consciousness. The displays were made in not ended conflicts, which demanded a diplomatic and military action to make succeed the negotiations. The powerlessness of UNO is characterized in the Darfour situation, where Sudan is condemned but not threatened. However, some belligerent parties sometimes should rather prolong the crisis to obtain a peace corresponding to their interests. The UNO did not know how to adapt itself to the reality of the crises.

There are difficulties mobilizing the democracies in the limited wars. The morality is often difficult to kick away. The behaviour of the conflicts turns in the marketing. The major question is then the way major powers define their interests and accept one degree of responsibility in the levels of conflict and use of the violence.

\section{F) Selective military humanitarian actions}

\footnotetext{
${ }^{4}$ For a complete analysis, see Sheehan, N. (2005), L'analyse économique des opérations de maintien de la paix de l'ONU, Thèse de doctorat, Grenoble.
} 
When the humanitarian when the massacres of the Serbs against Bosnian Moslem were broadcast, it will be necessary to wait 4 years so that the United States participates in important strikings against the Serbian positions. For the Europeans, it is a question of restoring the peace, even to the advantage of Serbia. For Clinton, it was a question of making justice to the victims of the Serbian aggression. There were thus differences in the Atlantic Alliance. On a cynical point of view, the ethnic cleaning facilitated the resolution of the conflict. The Americans appear as missionaries, asked to forbid the mistreated and starving children. Nevertheless, they will not so much consider in for the Serbian children.

The political international morality progressed. However, if the right progressed in Kuwait, that is from Chechnya, from Sudan or from the Tibet? Compared with the application of the clause of the most favoured Nation, the question of human rights passes in the background.

\section{II.3. The humanitarian as an instrument of domination}

Humanitarian policy constitutes an instrument of economic globalization and it appears as an interesting strategic instrument. We can neglect in the short run the economic advantages, even if the operations of preservation of the peace have an

important economic impact, with the purchases of possessions and 400 million dollar services, of which half in favour of the United States.

\section{A) Globalization and Humanitarian policy}

The American strategy is based on the shaping of the globalization. So, in his speech of the Union of January 27th, 2000, Clinton asserted that: " to realize all the opportunities of our economy, we have to exceed our borders and shape the revolution which brings down barriers and sets up new networks among nations and individuals, savings and cultures... We have to be in the centre of any global network. We have to admit that we cannot build our future without helping the others to build theirs ». There is three moments in this globalization:

- At first, is needed a consensus on the expansion of the international trade, with new standards and the opening of the markets of the South. The globalization, which leads to the growth of the actors outside the control of the State and the international law, has determining political and cultural effects. It is not enough to promote the free market and the integration, it is also necessary to implement policies of prevention. So, the national security intervenes in the international economic policy of the United States (allocation of the capital of the IMF, measure against the volatility of the capital, sales of weapons, etc.).

- Then, the United States favour the globalization to allow the American economy to benefit from the principle of the comparative advantages. For that purpose, this country wants to impose the own standards, to insure the normalization of markets. Any internal reform must be beforehand imposed on the international community, as well as the codes of conduct accepted by the American economic actors (as the laws anti-corruption, the economic sanctions, the sanitary standards or the environmental 
protection). The "humanitarian" policy joins at least partially in this ambition. The international hegemony became a factor of balance and internal imbalance. The national interest goes away from the notion of international public good, towards the exclusive search for the leadership and for the economic development, which accompanies it. In these conditions, if we can easily follow the policy of major powers when they insist with the International Labour Organization to develop the Labour Law all over the world, when they fight against the new corruptions been born in the new States. So, the defence of the children at work in the poor countries limits the unfair competition, but it does not give for all that any work to the adults of these countries. When the health is concerned, it worries more troubles of countries developed (AIDS) than those of the developing countries (malaria).

- Finally, the promotion of the democracy and the peace allows the integration of the former opponents in the liberalization process, the prevention of the conflicts when where the interests of Western countries are concerned or the fight against the economy of the crime and the corruption. The contemporary economy is a war field (boycott, embargo, unfair competition, etc.). It must be controlled by the international organizations, which forbid the humanitarian principles necessary for the normal functioning of the market. The economic assistance is not often mentioned, because the market economy is sensible to fight, eventually, against the poverty and the misery. To do it, it is necessary to develop the military and diplomatic power.

The question is to know if we want a war without death or deaths without war. The United States offer from now on only $0,14 \%$ of their GDP for the international aid, against $0,4 \%$ for Europe and 0,5\% for France. These sums are derisory, with regard to the American and Western strategic efforts. In other words, the humanitarian does not apply to the famine in the world, but rather to the disregard of the values of freedom. However, a help of the developed countries can lead to an evildevelopment. Some forms of international transfers turn out politically and economically expensive, notably when they are dedicated to the prestigious expenses, to the increase of the social disparities or to the development of the societies in which human rights are not inevitably respected. Transfers can also be the cause of dirty calculations of interest tending to accustom populations to a type of consumption making them dependent on industrial nations.

\section{B) An instrument of strategic choices}

The strategy is the art to combine the totality of the available means in order to be able to reach a State objective. For Clausewitz, there are two roads in the victory, the armed struggle or the control of the resources on which depends the opposition. It is the concept of global strategy.. Today, there was a virtual agreement between corrupt social groups and collusive western institutions. With the " diplomacy of the dollar », instead of paying for the disarmament and the development of Russia, it was considered preferable to pay to lesser costs by the corruption to have the same advantages in terms of disarmament. But quid the development?

The control of raw materials and energy materials becomes an important instrument of strategies for major powers. For the United States, it is a question of using all the appropriate means of the national power to influence the actors of the world 
economy. The command of the information is essential for the security. The case of the control of the petroleum is exemplary as such.

\section{Conclusion}

Any conception of the peace depends on philosophic positions on the human behaviour. The war and the conflicts are at first social factors due to the fight for the power, for the ideas (religions or ideologies) or to purely economic reasons. It is necessary to think about the violence suffered by the people, notably the economic disparities or the violence of the daily work. It would then be interesting to build indicators of security, to put in evidence the causes of conflicts, to underline the military and civilian threats (human rights, environment, relative poverty etc.), to determine the possible measures susceptible to bring remedies to every cause of insecurity, to establish a strategy capable of reducing all the factors of conflicts, by the application of a synthetic method.

It is thus necessary to build deliberately the peace and not only to dissuade the war. It is essential that peace is more attractive than war. The international security cannot be maintained in the long run within the framework of excessive economic and social effects of dominion or disparities. The economic development of Nations is a fundamental factor of the international security. But also, the defence of a country is a condition of its development.

\section{Références}

Fontanel, J. (1993), Economistes de la paix, Presses Universitaires de Grenoble, PUG, Grenoble.

Fontanel, J., Pecqueur, B. (2002), Economie politique de l'humanitairen in Globalisation économique et sécurité internationale. Introduction à la géoéconomie, Jacques Fontanel, Avant-propos de K.Arrow), Côté Cours, Grenoble, décembre.

Sheehan, N. (2005), L'analyse économique des opérations de maintien de la paix de l'ONU, Thèse de doctorat, Grenoble.

Sur, S. (1999), Aspects juridiques de l'intervention des pays membres de l'Otan au Kosovo ; Défense nationale ; Décembre, p.50.

Tinbergen, J. (1993), Paix économie, in «Economistes de la paix », .Fontanel, (Ed.) ; L’économie en plus, Presses Universitaires de Grenoble, Grenoble. 